\title{
REAKSI PASAR ATAS PENGUMUMAN PAKET KEBIJAKAN EKONOMI $X$ TENTANG DAFTAR NEGATIF INVESTASI
}

\author{
Gusti Ayu Surya Rosita Dewi ${ }^{1}$ \\ Dewa Gede Wirama ${ }^{2}$ \\ Ni Ketut Rasmini ${ }^{3}$ \\ 1,2,3 Fakultas Ekonomi dan Bisnis Universitas Udayana, Bali, Indonesia \\ email: ayurosita_dewi@yahoo.com
}

\begin{abstract}
ABSTRAK
Penelitian ini bertujuan menguji secara empiris reaksi pasar atas pengumuman Paket Kebijakan Ekonomi X tentang Daftar Negatif Investasi (DNI). Penelitian juga menguji perbedaan reaksi pasar antara sektor usaha yang diuntungkan dibandingkan dengan sektor usaha lainnya. Pengukuran menggunakan cumulative abnormal return (CAR). Sampel sebanyak 477 perusahaan yang terdaftar di Bursa Efek Indonesia. Teknik analisis data yang digunakan adalah one sample t-test dan independent sample t-test. Hasil analisis menunjukkan terdapat reaksi pasar positif atas pengumuman paket kebijakan ekonomi X dan terdapat perbedaan reaksi pasar antara sektor usaha yang diuntungkan dengan sektor usaha lainnya. Reaksi tertinggi diberikan oleh sektor usaha yang diuntungkan sedangkan sektor usaha lainnya memberikan reaksi yang rendah. Penelitian ini diharapkan dapat memberikan masukan bagi investor asing dalam berinvestasi di pasar modal. Bagi pemerintah dapat digunakan menyusun peraturan mengenai paket kebijakan ekonomi X dan menggunakan paket kebijakan ekonomi lainnya untuk menarik investor asing ke Indonesia.
\end{abstract}

Kata kunci: Reaksi pasar, paket kebijakan ekonomi X, daftar negatif investasi, abnormal return

\section{THE MARKET REACTION OF THE ANNOUNCEMENT OF ECONOMIC POLICY PACKAGE X ABOUT THE NEGATIVE INVESTMENT LIST}

\begin{abstract}
This study aims to empirically test the market reaction that occurs upon the announcement of Economic Policy Package X about the negative investment list (DNI). This study using event study method. The market reaction is calculated using cumulative abnormal return (CAR). The population used are all companies listed on the Indonesian Stock Exchange (BEI), 525 companies. The number of samples used are 477 companies. The analysis technique used is the one sample t-test and the independent sample t-test. The analysis showed that there is a positive market reaction to the announcement of the Economic Policy Package X. Furthermore, there are differences in the reaction that occurs between the business sectors that benefited by the policy than other business sectors. The highest reaction is shown by the business sectors that benefited by the policy. Business sectors which are benefited by the policy announcement obtained higher market reaction than their counterpart.
\end{abstract}

Keywords: Market reaction, economic policy package X, negative list investment, abnormal return DOI: https://doi.org/10.24843/JIAB.2017.v12.i01.p05

\section{PENDAHULUAN}

Pasar modal memiliki peranan penting bagi perekonomian suatu negara. Pemerintah dalam hal ini berupaya untuk meningkatkan peran pasar modal karena peranannya dalam pembangunan nasional sebagai salah satu sumber pembiayaan bagi dunia usaha dan sarana investasi bagi masyarakat. Sebagai salah satu instrumen perekonomian, maka pasar modal tidak terlepas dari pengaruh yang berkembang di lingkungannya. Pengaruh tersebut dari lingkungan ekonomi mikro seperti peristiwa atau keadaan para emiten, seperti laporan kinerja, pembagian deviden, perubahan strategi perusahaan atau keputusan strategis dalam rapat umum pemegang saham. Di samping lingkungan ekonomi mikro, perubahan lingkungan yang dimotori oleh kebijakan-kebijakan makro ekonomi kebijakan moneter, kebijakan fiskal maupun regulasi pemerintah dalam sektor riil dan keuangan, akan pula mempengaruhi gejolak di pasar modal (Suryawijaya dan Setiawan, 1998). 
Sejak berdirinya pasar modal Indonesia konstribusi investor asing selalu lebih besar, dengan kata lain mereka yang lebih banyak menikmati keuntungan akibat pertumbuhan ekonomi tersebut (Chandra, 2010). Ketika investor asing melakukan pembelian besar-besaran, harga saham naik dengan cepat, begitu juga sebaliknya, aktivitas investor asing seringkali menjadi barometer karena dianggap memberi pengaruh besar terhadap harga saham (May, 2012).

Kepemilikan nilai saham investor asing dan lokal dari bulan Januari 2015 sampai Maret 2016 masih berfluktuasi, tidak adanya peningkatan kepemilikan saham investor asing yang terjadi. Kepemilikan nilai saham investor asing lebih tinggi dibandingkan investor lokal, hanya saja penyebaran investasi asing masih kurang di beberapa bidang usaha. Maka dari itu masih perlunya strategi untuk menarik investor asing masuk ke Indonesia. Dikutip dari Dieng Pos (2016), Menko Perekonomian Darmin Nasution menjelaskan perlunya memperluas kesempatan kepada asing untuk masuk, karena ingin mengembangkan investasi nasional yang dinilai tidak banyak disentuh. Misalnya saja pada industri bahan baku obat yang dinilai selama ini sekitar $90 \%$ impor yang menyebabkan harga obat masih tinggi, dan industri cold storage yang sampai sekarang tidak berkembang.

Masyarakat Ekonomi ASEAN (MEA) yang sudah masuk ke Indonesia, juga menyebabkan Pemerintah untuk mengantisipasi era persaingan. Caranya dengan menarik investor asing masuk lebih banyak ke Indonesia untuk memacu pertumbuhan ekonomi dan memperkuat modal perusahaan Nasional. Tujuan dari antisipasi tersebut agar perusahaan Nasional mampu bersaing dan semakin kuat di pasar dalam negeri maupun pasar global. Maka dari itu, Pemerintah membentuk sebuah peraturan yaitu paket kebijakan ekonomi X tentang daftar negatif investasi (DNI). Revisi DNI dilakukan untuk memotong mata rantai pemusatan ekonomi yang selama ini dinikmati oleh kelompok tertentu, dengan demikian harga barang dapat ditekan menjadi semakin murah.

Daftar negative investasi (DNI) merupakan implementasi dari prinsip transparansi, agar investor dapat dengan mudah mengetahui bidang-bidang usaha yang tertutup atau terbuka dengan persyaratan yang dapat dimasuki oleh penanam modal. Daftar negatif investasi yang direvisi kembali oleh Pemerintah yaitu bagi investor asing, dimana kepemilikan saham investor asing ditingkatkan mencapai 49 persen, 67 persen dan 100 persen. Hal ini menyebabkan adanya sektor usaha yang diuntungkan yaitu sektor pertanian, sektor industri barang konsumsi pada sub sektor farmasi, sektor properti, real estate dan konstruksi bangunan, sektor infrastruktur, utilitas dan transportasi serta sektor perdagangan, jasa dan investasi. Sedangkan untuk sektor usaha lainnya ialah sektor pertambangan, sektor industri, dasar dan kimia, sektor aneka industri, sektor industri barang konsumsi serta sektor keuangan.

Penelitian untuk menguji kandungan informasi dari pengumuman paket kebijakan ekonomi $\mathrm{X}$ dilakukan dengan cara mengukur kekuatan hubungan antara pengumuman paket kebijakan ekonomi $\mathrm{X}$ dengan harga atau return saham. Cara lain untuk menguji kandungan suatu informasi adalah dengan melihat perilaku reaksi pasar. Reaksi pasar ditunjukkan dari perubahan harga dari sekuritas bersangkutan. Reaksi ini dapat diukur dengan menggunakan return sebagai nilai perubahan harga atau dengan menggunakan abnormal return. Dengan menggunakan abnormal return maka dapat dikatakan bahwa suatu pengumuman yang mempunyai kandungan informasi akan memberikan abnormal return pada pasar, sebaliknya pengumuman yang tidak mengandung informasi tidak memberikan abnormal return pada pasar (Hartono, 2014).

Berbagai penelitian yang telah dilakukan berkaitan dengan reaksi pasar yaitu Ashley (1962) menguji harga saham dan perubahan laba dan dividen. Menghasilkan perubahan harga saham pada perusahaan yang memiliki berita buruk berbeda dengan perusahaan yang memiliki berita baik. Harga saham berubah lebih cepat pada berita buruk dan lebih lambat pada berita baik. Maharani (2014) menguji respon pasar atas informasi laba, menghasilkan bahwa pasar merespon informasi laba kejutan, dan respon tersebut searah dengan informasi laba yang diumumkan.

Malhotra et. al., (2007) meneliti mengenai reaksi pasar saham dan perubahan likuiditas disekitar pengumuman bonus. Dihasilkan adanya reaksi negatif setelah pengumuman bonus, dinyatakan dengan pasar tidak bereaksi setelah pengumuman tersebut, dan diamati ternyata tidak ada kebocoran informasi sebelum pengumuman. Gelb (2000) menguji reaksi investor terhadap pengumuman dividen dan pembelian kembali saham. Dihasilkan bahwa pengumuman dividen memberikan sinyal positif terhadap investor dibandingkan dengan pengumuman pembelian kembali saham.

Berdasarkan penjelasan di atas, penelitian ini menarik untuk diteliti karena dari fenomena yang 
terjadi bahwa kepemilikan nilai saham investor asing selama bulan Januari 2015 sampai Maret 2016 mengalami fluktuasi dan tidak ada peningkatan. Selain itu, penyebaran investasi oleh investor asing masih kurang di beberapa bidang usaha, terutama di luar Jawa yang porsi saat ini berkisar 42 persen. Investasi nasional yang dinilai tidak banyak disentuh, misalnya harga obat masih tinggi karena bahan baku obat 90 persen masih impor, dan industri cold storage yang sampai sekarang tidak berkembang (Dieng Pos, 2016).

Rumusan masalah dalam penelitian ini adalah apakah pasar modal bereaksi terhadap pengumuman paket kebijakan ekonomi X tentang Daftar Negatif Investasi (DNI)? dan apakah terdapat perbedaan reaksi pasar antara sektor usaha yang diuntungkan oleh pengumuman paket kebijakan ekonomi X dibandingkan dengan sektor usaha lainnya?. Tujuan penelitian ini untuk menguji ada tidaknya reaksi pasar saham sebagai dampak dari pengumuman paket kebijakan ekonomi X tentang Daftar Negatif Investasi (DNI) dan untuk menguji perbedaan reaksi pasar antara sektor usaha yang diuntungkan oleh pengumuman paket kebijakan ekonomi X dibandingkan dengan sektor usaha lainnya.

Manfaat dari penelitian ini ialah dapat dijadikan acuan dalam menentukan reaksi pasar atas sebuah pengumuman karena hasil penelitian menyatakan pasar memberikan reaksi positif terhadap pengumuman paket kebijakan ekonomi X. Hal ini dapat memberikan masukan bagi investor agar dapat digunakan sebagai bahan pertimbangan dalam berinvestasi di pasar modal. Bagi pemerintah, dapat digunakan dalam menyusun peraturan lebih lanjut mengenai paket kebijakan ekonomi $\mathrm{X}$ agar seluruh perusahaan mendapatkan manfaat dari paket kebijakan ekonomi selanjutnya.

Teori sinyal merupakan dorongan perusahaan untuk memberikan informasi kepada pihak eksternal untuk mengurangi asimetri informasi (Fidhayatin, 2012). Hartono (2014) menjelaskan bahwa informasi yang dipublikasikan sebagai suatu pengumuman akan memberikan sinyal bagi investor dalam pengambilan keputusan investasi. Sinyal perubahan dapat dilihat dari reaksi harga saham. Reaksi tersebut dapat berupa reaksi positif dan reaksi negatif.

Pada penelitian ini, pemerintah mengeluarkan pengumuman mengenai paket kebijakan ekonomi X yang diduga memiliki kandungan informasi yang mengakibatkan adanya reaksi harga saham. Pengumuman paket kebijakan ekonomi X digunakan oleh para investor sebagai sinyal atau isyarat tentang prospek perusahaan di masa yang akan datang.
Investor akan mengambil keputusan untuk melakukan transaksi atau menundanya setelah membaca adanya sinyal yang dibaca di lantai bursa. Ketika sinyal yang dibaca di lantai bursa menunjukkan sinyal positif maka investor lebih banyak melakukan transaksi pembelian dari pada penjualan. Hal ini terjadi karena investor berasumsi bahwa ketika terjadi sinyal positif sebagian investor optimis melakukan transaksi dengan harapan mendapatkan keuntungan yang lebih besar.

Hipotesis pasar efisien dipopulerkan oleh Eugene Fama pada tahun 1970. Pada dasarnya hipotesis ini menyatakan bahwa pasar disebut efisien jika hargaharga saham mencerminkan seluruh informasi yang tersedia secara penuh dan cepat. Informasi tersebut tidak terbatas hanya pada informasi keuangan saja, tetapi juga mencakup informasi politik, kejadian sosial ekonomi dan informasi lainnya. (Amyulianthy dkk, 2013). Untuk mengetahui kebenaran dari hipotesis pasar efisien, maka perlu dilakukan pengujian secara empiris untuk masing-masing bentuk efisiensi pasar.

Studi peristiwa dapat digunakan untuk menguji efisiensi pasar bentuk setengah kuat. Studi peristiwa menurut Hartono (2014:623) merupakan studi yang mempelajari reaksi pasar terhadap suatu peristiwa yang informasinya dipublikasikan sebagai suatu pengumuman. Reaksi pasar ditunjukkan dari perubahan harga dari sekuritas bersangkutan. Reaksi ini dapat diukur dengan menggunakan return sebagai nilai perubahan harga atau dengan menggunakan abnormal return.

Return merupakan tingkat kembalian yang dinikmati oleh investor atas suatu investasi yang dilakukannya. Menurut Ang (1997) tanpa adanya keuntungan yang dapat dinikmati dari suatu investasi, tentunya investor tidak akan mau berinvestasi. Return dapat berupa return realisasi yang sudah terjadi atau return ekspektasi yang belum terjadi tetapi diharapkan terjadi di masa yang akan datang. Hartono (2014) mendefinisikan return realisasi sebagai return yang telah terjadi yang dapat dihitung berdasarkan data historis. Sedangkan return ekspektasi adalah return yang diharapkan akan diperoleh investor di masa mendatang. Berbeda dengan return realisasi, return ekspektasi sifatnya belum terjadi.

Studi peristiwa menganalisis abnormal return dari sekuritas yang mungkin terjadi di sekitar pengumuman dari suatu peristiwa. Abnormal return merupakan kelebihan dari return normal. Return normal merupakan return ekspektasi (return yang diharapkan oleh investor). Dengan demikiaan return takormal adalah selisih antara return sesungguhnya yang terjadi dengan return ekspektasi. 
Pengumuman-pengumuman yang berhubungan dengan pemerintah seperti dampak dari peraturan baru, investigasi-investigasi terhadap kegiatan perusahaan, keputusan-keputusan regulator dan lainnya, dapat mempengaruhi harga dari sekuritas (Hartono, 2014). Salah satu pengumuman dari pemerintah yang baru diumumkan tanggal 11 Februari 2016 yaitu paket kebijakan ekonomi X mengatur tentang DNI bagi investor asing.

Pengumuman paket kebijakan ekonomi X merupakan informasi yang dipublikasikan yang mempengaruhi harga-harga sekuritas semua perusahaan yang terdaftar di pasar saham. Informasi yang diberikan oleh paket kebijakan ekonomi $\mathrm{X}$ yaitu mengenai DNI bagi investor asing. Investor asing diberikan peluang dalam berinvestasi di Indonesia dengan meningkatkan komposisi saham asing masing-masing sebesar 49 persen, 67 persen dan 100 persen. Otomatis investor akan memberikan reaksi terhadap pengumuman paket kebijakan ekonomi X. Bagi investor pengumuman paket kebijakan ekonomi $\mathrm{X}$ memberikan informasi dan keuntungan bagi investor dalam berinvestasi dari adanya peningkatan komposisi saham tersebut. Keuntungan yang diinginkan oleh investor tentu saja berupa return yang akan di dapat dari hasil investasi yang telah dilakukan.

Kandungan informasi dari paket kebijakan ekonomi X diharapkan pasar akan bereaksi pada waktu pengumuman tersebut diterima oleh pasar. Reaksi tersebut diukur dengan abnormal return. Maka dapat dikatakan bahwa, suatu pengumuman yang mempunyai kandungan informasi akan memberikan return tak normal pada pasar, sebaliknya pengumuman yang tidak mengandung informasi tidak memberikan return tak normal pada pasar (Hartono, 2014).

Sesuai dengan hipotesis pasar efisien bahwa pasar akan mencerminkan secara penuh dalam menghimpun informasi ke harga saham ketika informasi tersebut dikeluarkan (Jabin, 2012). Beberapa penelitian terdahulu yang meneliti mengenai reaksi pasar yang berhubungan dengan pengumuman dari pemerintah yaitu Oberndorfer dan Ziegler (2006), Hall dan Kenjegaliev (2009), Kumar dan Seema (2009), serta Harlanta (2016). Dari uraian tersebut dapat dibentuk hipotesis penelitian adalah:

$\mathrm{H}_{1}$ : Terdapat reaksi pasar atas pengumuman paket kebijakan ekonomi $\mathrm{X}$ tentang daftar negatif investasi (DNI)

Paket kebijakan ekonomi X merevisi kembali DNI dengan mengeluarkan 35 bidang usaha dari DNI. Dimana komposisi saham investor asing ditingkatkan mencapai 49 persen, 67 persen dan 20 bidang usaha diantaranya komposisi saham investor asing meningkat sebesar 100 persen. Adanya pengumuman paket kebijakan ekonomi $\mathrm{X}$ artinya perusahaan memberikan sinyal kepada pemegang saham. Teori sinyal merupakan dorongan perusahaan untuk memberikan informasi kepada pihak eksternal untuk mengurangi asimetri informasi (Fidhayatin, 2012). Sinyal yang diberikan oleh perusahaan berupa informasi, baik finansial maupun non finansial diharapkan memberikan dampak yang positif terhadap penilaian perusahaanya. Hal ini dapat membantu investor dalam rangka menganalisis keputusan investasi.

Pengumuman paket kebijakan ekonomi X menyebabkan adanya sektor usaha yang diuntungkan yaitu sektor pertanian, sektor industri barang konsumsi pada sub sektor farmasi, sektor properti, real estate dan konstruksi bangunan, sektor infrastruktur, utilitas dan transportasi serta sektor perdagangan, jasa dan investasi. Sektor usaha lainnya, terdiri dari sektor pertambangan, sektor industri dasar dan kimia, sektor aneka industri, sektor industri barang konsumsi dan sektor keuangan. Penelitian terdahulu yang meneliti mengenai reaksi pasar dengan adanya pengumuman dari pemerintah yaitu Hunton, Reck dan Hayes (1999), Agrawal, Kishore dan Rao (2006), Aktas, Bodt dan Roll (2004), Ira (2005) serta Fitriani (2014). Dari uraian tersebut, dapat dibentuk hipotesis penelitian adalah:

$\mathrm{H}_{2}$ : Terdapat perbedaan reaksi pasar antara sektor usaha yang diuntungkan atas pengumuman paket kebijakan ekonomi $\mathrm{X}$ dibandingkan dengan sektor usaha lainnya.

\section{METODE PENELITIAN}

Data yang digunakan dalam penelitian ini adalah data sekunder yang diperoleh dari Bursa Efek Indonesia (www.idx.co.id) dan yahoo finance (www.finance.yahoo.com). Jenis data yang digunakan adalah data kuantitatif. Data kuantitatif yaitu data dalam bentuk angka-angka atau data kualitatif yang diangkakan (Sugiyono, 2014). Data kuantitatif dalam penelitian ini adalah harga saham harian dan Indeks Harga Saham Gabungan (IHSG) harian selama tujuh hari peristiwa. Sumber data dalam penelitian ini adalah sumber data sekunder. Sumber data sekunder adalah data yang diperoleh dari informasi perusahaan (Sugiyono, 2014). Data sekunder dalam penelitian ini seperti daftar namanama perusahaan yang diteliti harga sahamnya atau sumber-sumber terkait dan isi peraturan dari paket kebijakan ekonomi X. 
Populasi adalah wilayah generalisasi yang terdiri atas objek atau subjek yang mempunyai kualitas dan karakteristik tertentu yang ditetapkan oleh peneliti untuk dipelajari dan kemudian ditarik kesimpulannya (Sugiyono, 2014). Populasi dalam penelitian ini adalah seluruh perusahaan yang terdaftar di Bursa Efek Indonesia tahun 2016 yaitu 525 perusahaan. Sampel adalah bagian dari jumlah dan karakteristik yang dimiliki oleh populasi (Sugiyono, 2014). Teknik sampel yang digunakan dengan metode nonprobability sampling yang dipilih menggunakan purposive sampling, yaitu teknik pengambilan sampel berdasarkan kriteria tertentu. Sampel yang digunakan dalam penelitian sebanyak 477 perusahaan, dengan kriteria 1) Selama periode peristiwa perusahaan tidak melakukan corporate action lain seperti pengumuman dividen tunai, dividen saham, right issue, saham bonus, merger, akuisisi, stock split, reverse stock untuk menghindari terjadinya bias karena adanya informasi lain; 2) perusahaan memiliki informasi yang lengkap mengenai harga saham selama penelitian. Informasi harga saham yang lengkap dimaksudkan karena penelitian ini menggunakan perhitungan return ekspektasi mean adjusted model dengan menghitung rata-rata return selama 100 hari yaitu mulai dari 9 September 2015 sampai 4 Februari 2016. Dimana terdapat beberapa perusahaan yang baru listing di Bursa Efek Indonesia setelah bulan September 2015 dan harga saham perusahaan tersebut tidak ada, maka perusahaan yang listing setelah bulan September 2015 tidak digunakan.

Proses pemilihan sampel berdasarkan kriteria yang telah ditetapkan disajikan dalam Tabel 1.

Tabel 1.

\section{Sampel Penelitian}

\begin{tabular}{llc}
\hline No & \multicolumn{1}{c}{ Kriteria } & Jumlah \\
\hline 1 & $\begin{array}{l}\text { Populasi } \\
\text { Perusahaan yang melakukan } \\
\text { corporate action }\end{array}$ & 525 \\
3 & $\begin{array}{l}\text { Perusahaan yang tidak memiliki } \\
\text { informasi lengkap mengenai } \\
\text { harga saham selama penelitian }\end{array}$ & $(39)$ \\
& \\
\hline Jumlah Sampel & 477 \\
\hline
\end{tabular}

Sumber : Data diolah, 2016

Variabel yang akan dianalisis dalam penelitian ini terdiri dari variabel dependen dan variabel independen. Variabel dependen penelitian ini adalah reaksi pasar yang diukur oleh Cumulative Abnormal Return (CAR) selama tujuh hari peristiwa. Variabel independen penelitian ini adalah peristiwa pengumuman paket kebijakan ekonomi X.
Studi peristiwa digunakan dalam penelitian ini untuk menguji reaksi pasar dari pengumuman paket kebijakan ekonomi X yang diumumkan pada tanggal 11 Februari 2016. Periode penelitian yang digunakan dalam studi peristiwa ini adalah selama tujuh hari, tiga hari perdagangan saham sebelum terjadinya peristiwa ( $\mathrm{t}-3$ ) hingga tiga hari perdagangan saham setelah terjadinya peristiwa $(t+3)$. Alasan pengambilan periode penelitian -3 dan +3 adalah untuk menghindari adanya corporate action di luar peristiwa paket kebijakan ekonomi X seperti akibat pengumuman dividen tunai, dividen saham, right issue, saham bonus, merger, akuisisi, stock split, reverse stock.

Adapun untuk memprediksi return selama periode peristiwa, diambil periode estimasi selama 100 hari, yaitu dari 103 hari perdagangan saham sebelum terjadinya peristiwa (t-103) hingga 4 hari perdagangan saham sebelum terjadinya peristiwa ( $\mathrm{t}-$ 4). Periode estimasi selama 100 hari ini diasumsikan sudah memadai untuk memprediksi return selama periode peristiwa. Tidak ada patokan untuk lamanya periode estimasi ini, lama periode estimasi yang umum digunakan adalah berkisar dari 100 hari sampai dengan 250 hari atau selama setahun untuk hari-hari perdagangan (Hartono, 651:2014).

Pertama yang dilakukan sebelum menguji hipotesis adalah menghitung return realisasi, return ekspektasi, abnormal return setelah itu cumulaive abnormal return (CAR). Return realisasi adalah return nyata yang terjadi pada masing-masing saham di Bursa Efek Indonesia. Metode perhitungan return realisasi yang digunakan adalah return total yaitu dengan menggunakan capital gain (loss), dengan rumus sebagai berikut (Hartono, 2014):

$$
\mathrm{CG} \text { atau } \mathrm{CL}=\frac{P_{i t}-P i_{t-1}}{P_{i t-1}}
$$

Keterangan:

CG atau CL = Capital Gain atau Capital Loss

$\mathrm{P}_{i t} \quad=$ harga sekuritas ke-i pada periode ke-t

$\mathrm{P}_{t-1} \quad=$ harga sekuritas ke-i pada periode ke-t-1

Perhitungan return ekspektasi dalam penelitian ini menggunakan mean adjusted model karena merupakan perhitungan yang sederhana dan mencerminkan return ekspektasi yang bernilai konstan yang sama dengan rata-rata -return realisasian sebelumnya selama periode estimasi. Perhitungan return ekspektasi dilakukan sebagai dasar dari perhitungan abnormal return, dengan rumus sebagai berikut (Hartono, 2014): 


$$
\mathrm{E}\left(\mathrm{R}_{\mathrm{it}}\right)=\frac{\sum_{j=t 1}^{t^{2}} R_{i, j}}{\mathrm{~T}}
$$

Keterangan:

$\mathrm{E}(\mathrm{Ri}, \mathrm{t})=$ return ekspektasi sekuritas ke-i untuk periode peristiwa ke-t

$\mathrm{Ri}, \mathrm{j}=$ return realisasi saham ke-i pada periode estimasi ke-t

$\mathrm{T}$ = lamanya periode estimasi, yaitu dari $\mathrm{t} 1$ sampai 2

Abnormal return adalah selisih antara return sesungguhnya yang terjadi dengan return ekspektasi. Abnormal return dihitung dengan rumus sebagai berikut (Hartono, 2014):

$$
\mathrm{RTN}_{\mathrm{i}, \mathrm{t}}=\mathrm{R}_{\mathrm{i}, \mathrm{t}}-\mathrm{E}\left[\mathrm{R}_{\mathrm{i}, \mathrm{t}}\right] .
$$

Keterangan:

$\mathrm{RTN}_{\mathrm{it}}=$ abnormal return sekuritas ke-i pada periode ke-t

$\mathrm{R}_{\mathrm{it}} \quad=$ return sesungguhnya yang terjadi untuk sekuritas ke-i pada periode ke-t

$\mathrm{E}\left(\mathrm{R}_{\mathrm{it}}\right)=$ return ekspektasi sekuritas ke-i pada periode peristiwa ke-t

Cumulative abnormal return (CAR) merupakan penjumlahan abnormal return hari sebelumnya di dalam periode peristiwa untuk masingmasing sekuritas, dengan rumus sebagai berikut (Hartono, 2014):

$$
\mathrm{CAR}=\sum_{\mathrm{a}=\mathrm{t} 3}^{\mathrm{t}} \mathrm{AR}_{\mathrm{i}, \mathrm{a}}
$$

Keterangan:

CAR = akumulasi abnormal return sekuritas ke-i pada hari ke-t, yang diakumulasi dari abnormal return (AR) sekuritas ke-i mulai hari awal periode peristiwa (t3) sampai hari ke-t

$\mathrm{AR}_{\mathrm{i}, \mathrm{a}}=$ abnormal return untuk sekuritas ke-i pada hari ke-a, yaitu mulai $\mathrm{t} 3$ (hari awal periode jendela) sampai hari ke-t

Uji sensitivitas juga digunakan dalam penelitian ini. Uji sensitivitas digunakan untuk pengujian tambahan atas model penelitian utama yang diuji. Model penelitian utama yang digunakan adalah menghitung return ekpektasi menggunakan mean adjusted model dan dengan uji sensitivitas menggunakan return ekpektasi dengan market adjusted model. Uji sensitivitas ini dilakukan untuk memperkuat kemungkinan yang kita lakukan yang biasanya menggunakan alat ukur yang berbeda. Kemungkinan yang dimaksud adalah bahwa pengumuman paket kebijakan ekonomi $\mathrm{X}$ benarbenar memberikan reaksi terhadap pasar walaupun menggunakan alat ukur yang berbeda.

Uji sensitivitas variabel dependen Cumulative Abnormal Return (CAR) dilakukan dengan menggunakan metode market adjusted model dalam menghitung return ekspektasi. Rumus yang digunakan untuk menghitung return ekspektasi adalah sebagai berikut (Hartono, 2014:659):

$$
E\left(R_{i, t}\right)=\frac{I H S G_{i t}-I_{H S G} i t-1}{I_{H S G}}
$$

Keterangan:

$\mathrm{E}\left(\mathrm{R}_{\mathrm{it}}\right)=$ return ekspektasi sekuritas-i pada hari ke-t

$\mathrm{IHSG}_{\mathrm{it}}=$ indeks harga saham gabungan pada hari ke-t

$\mathrm{IHSG}_{\mathrm{it}-1}=$ indeks harga saham gabungan pada hari ke-t-1

Setelah menghitung Cumulative Abnormal Return (CAR) menggunakan market adjusted model lalu dilakukan kembali uji one sample t-test dan independent sample t-test.

Tahap selanjutnya setelah menghitung return yaitu melakukan analisis data terlebih dahulu dengan melakukan uji statistik deskriptif. Uji statistik deskriptif dalam penelitian ini digunakan untuk memberikan gambaran atau deskriptif suatu data yang dilihat dari nilai minimum, maksimum, rata-rata, dan standar deviasi mengenai cumulative abnormal return (CAR) selama periode penelitian. Selanjutnya, uji normalitas digunakan untuk mengetahui data berdistribusi normal atau tidak. Metode pengujian normalitas yang dilakukan menggunakan uji Kolmogorov-Smirnov.

Pengujian hipotesis menggunakan one sample t-test, uji ini dilakukan untuk menguji hipotesis pertama yaitu untuk menguji ada tidaknya reaksi pasar atas pengumuman paket kebijakan ekonomi $\mathrm{X}$. Pengujian hipotesis kedua menggunakan independent sample t-test bertujuan untuk mengetahui ada atau tidaknya perbedaan rata-rata antara dua kelompok sampel yang berbeda. Uji ini dilakukan untuk pengujian hipotesis kedua yaitu ada tidaknya perbedaan reaksi antara sektor usaha yang diuntungkan atas pengumuman paket kebijakan ekonomi $\mathrm{X}$ dengan sektor usaha lainnya. 


\section{HASIL DAN PEMBAHASAN}

Hasil dari statistik deskriptif yang memberikan gambaran atau deskriptif suatu data yang dilihat dari nilai minimum, maksimum, rata-rata, dan standar deviasi, disajikan pada Tabel 2 .

Berdasarkan Tabel 2, return realisasi yang dihitung menggunakan return total dengan jumlah sampel sebanyak 477 perusahaan selama tujuh hari pengamatan memiliki nilai minimum sebesar $-0,032$ dan nilai maksimum sebesar 0,123 . Rata-rata return realisasi sebesar 0,001 dengan standar deviasi 0,010 yang berarti selama tujuh hari pengamatan investor mendapatkan return realisasi sebesar 0,001 .

Return ekspektasi dihitung menggunakan mean adjusted model dengan sampel sebanyak 477

Tabel 2.

Statistik Deskriptif

\begin{tabular}{llrrrr}
\hline & N & Minimum & Maximum & Mean & Std. Deviation \\
\hline Return Realisasi & 477 & $-0,032$ & 0,123 & 0,001 & 0,010 \\
Return Ekspektasi & & & & & \\
(mean adjusted model) & 477 & $-0,043$ & 0,017 & 0,001 & 0,004 \\
CAR seluruh sektor & 477 & $-0,194$ & 0,839 & 0,009 & 0,078 \\
CAR sektor usaha yang & 233 & $-0,194$ & 0,839 & 0,017 & 0,092 \\
diuntungkan & 254 & $-0,185$ & 0,376 & 0,003 & 0,062 \\
CAR sektor usaha lainnya & & & & &
\end{tabular}

Sumber: Data diolah, 2016

perusahaan, menghasilkan return ekspektasi minimum sebesar -0,043 dan nilai maksimum sebesar 0,017. Rata-rata return ekspektasi sebesar 0,001 dengan standar deviasi 0,004 yang berarti selama tujuh hari pengamatan investor memiliki return ekspektasi dengan rata-rata sebesar 0,001.

Cumulative abnormal return (CAR) secara keseluruhan dengan 477 perusahaan yang digunakan selama tujuh hari pengamatan, diperoleh nilai minimum CAR sebesar -0,194 dan nilai maksimum CAR sebesar 0,839 . Nilai rata-rata CAR sebesar 0,009 dengan standar deviasi sebesar 0,078. Ratarata CAR yang bernilai positif menunjukkan bahwa pengumuman paket kebijakan ekonomi X memiliki kandungan informasi bagi seluruh sektor.

Statistik deskriptif untuk sektor usaha yang diuntungkan atas pengumuman paket kebijakan ekonomi X selama tujuh hari pengamatan sebanyak 223 perusahaan dengan nilai CAR minimum sebesar -0,194 dan nilai maksimum CAR sebesar 0,839. Rata-rata CAR sebesar 0,017 dan standar deviasi sebesar 0,092. Rata-rata CAR selama periode pengamatan adalah positif menunjukkan bahwa, pengumuman paket kebijakan ekonomi $\mathrm{X}$ memiliki kandungan informasi bagi sektor usaha yang diuntungkan.

Statistik deskriptif sektor usaha lainnya yang diteliti selama tujuh hari pengamatan sebanyak 254 perusahaan dengan nilai CAR minimum $-0,185$ dan nilai CAR maksimum sebesar 0,376. Rata-rata CAR sebesar 0,002 dan standar deviasi sebesar 0,062. Rata-rata CAR selama periode pengamatan adalah positif menunjukkan bahwa pengumuman paket kebijakan ekonomi X memiliki kandungan informasi bagi sektor usaha lainnya.

Hasil penelitian uji normalitas menggunakan variabel CAR menghasilkan nilai probabilitas sebesar $0,315>0,05$. Hal ini berarti bahwa semua data cumulative abnormal return (CAR) pada peristiwa pengumuman paket kebijakan ekonomi $\mathrm{X}$ terdistribusi normal.

Uji one sample $t$-test dilakukan untuk menguji hipotesis 1 yaitu ada tidaknya reaksi pasar atas pengumuman paket kebijakan ekonomi $\mathrm{X}$ tentang daftar negatif investasi. Variabel yang digunakan adalah cumulative abnormal return (CAR). Hasil pengujian disajikan pada Tabel 3 sebagai berikut.

Tabel 3.

Hasil Uji One Sample t-test

\begin{tabular}{lcccccc}
\hline \multicolumn{4}{c}{ Test Value $=0$} \\
\hline & & & \\
& & & & \multicolumn{2}{c}{$\begin{array}{c}95 \% \text { Confidence } \\
\text { Interval of the } \\
\text { Difference }\end{array}$} \\
\hline & $\mathrm{t}$ & Df & Sig. (2-tailed) & Mean Difference & Lower & Upper \\
CAR & 2,585 & 476 & 0,010 & 0,009 & 0,002 & 0,016 \\
\hline Sumber: Data diolah, 2016 & & & & &
\end{tabular}


Berdasarkan Tabel 3 dihasilkan bahwa cumulative abnormal return (CAR) selama periode pengamatan memperoleh nilai $\mathrm{t}=2,585$ dengan nilai probabilitas sebesar 0,010 . Nilai probabilitas $0,010<$ $\alpha(0,05)$, yang berarti hipotesis 1 diterima. Hal ini sesuai dengan Hartono (2014), yang menyatakan bahwa terdapat respon pasar atas pengumuman paket kebijakan ekonomi X tentang daftar negatif investasi.

Tabel 4.

Hasil Uji Independent Sample t-test

\begin{tabular}{|c|c|c|c|c|c|c|c|c|}
\hline & & \multicolumn{7}{|c|}{ t-test for Equality of Means } \\
\hline & & & & & & & $\begin{array}{r}95 \% \mathrm{Co} \\
\text { Interva } \\
\text { Diffe }\end{array}$ & $\begin{array}{l}\text { fidence } \\
\text { of the } \\
\text { ence }\end{array}$ \\
\hline & & $\mathrm{t}$ & Df & $\begin{array}{l}\text { Sig. (2- } \\
\text { tailed) }\end{array}$ & $\begin{array}{c}\text { Mean } \\
\text { Difference }\end{array}$ & $\begin{array}{l}\text { Std. Error } \\
\text { Difference }\end{array}$ & Lower & Upper \\
\hline \multirow[t]{2}{*}{ CAR } & $\begin{array}{l}\text { Equal } \\
\text { variances } \\
\text { assumed } \\
\end{array}$ & 1,980 & 475 & 0,048 & 0,014 & 0,007 & 0,000 & 0,028 \\
\hline & $\begin{array}{l}\text { Equal } \\
\text { variances not } \\
\text { assumed }\end{array}$ & 1,932 & 381,853 & 0,044 & 0,014 & 0,007 & $-0,000$ & 0,028 \\
\hline
\end{tabular}

Sumber: Data diolah, 2016

Independent sample t-test dilakukan untuk menguji hipotesis 2 yaitu ada tidaknya perbedaan reaksi pasar antara sektor usaha yang diuntungkan atas pengumuman paket kebijakan ekonomi $\mathrm{X}$ dengan sektor usaha lainnya.

Pada Tabel 4 hasil uji independent sample t-test menunjukkan nilai probabilitas sebesar $0,048<\alpha(0,05)$, yang artinya. hipotesis 2 diterima bahwa terdapat perbedaan reaksi pasar antara sektor usaha yang diuntungkan atas pengumuman paket kebijakan ekonomi X dengan sektor usaha lainnya. Uji sensitivitas juga dilakukan dalam penelitian ini untuk memperkuat kemungkinan yang dilakukan. Kemungkinan yang dimaksud adalah bahwa pengumuman paket kebijakan ekonomi $\mathrm{X}$ benarbenar memberikan reaksi terhadap pasar walaupun menggunakan alat ukur yang berbeda. Hasil uji sensitivitas yang menggunakan metode perhitungan return ekspektasi market adjusted model memberikan hasil yang sama-sama signifikan dengan perhitungan utama yang digunakan yaitu perhitungan mean adjusted model. Berarti pengumuman paket kebijakan ekonomi $\mathrm{X}$ benar-benar memiliki kandungan informasi bagi pelaku pasar, walaupun dengan menggunakan perhitungan yang berbeda dalam menentukan CAR.

Hasil dari penelitian menyatakan hipotesis pertama, diterima, bahwa pasar bereaksi terhadap pengumuman paket kebijakan ekonomi $\mathrm{X}$ tentang daftar negatif investasi (DNI). Artinya pengumuman paket kebijakan ekonomi $\mathrm{X}$ tentang daftar negatif investasi (DNI) bagi para investor sangat penting karena menyangkut perubahan komposisi investor asing pada masing-masing perusahaan. Informasi yang diberikan oleh paket kebijakan ekonomi $\mathrm{X}$ yaitu mengenai DNI bagi investor asing. Investor asing diberikan peluang dalam berinvestasi di Indonesia dengan meningkatkan komposisi saham asing masing-masing sebesar 49 persen, 67 persen dan 100 persen. Bagi investor, pengumuman paket kebijakan ekonomi X memberikan informasi dan keuntungan bagi investor dalam berinvestasi dari adanya peningkatan komposisi saham tersebut. Keuntungan yang diinginkan oleh investor tentu saja berupa return yang akan di dapat dari hasil investasi yang telah dilakukan.

Pergerakan indeks harga saham gabungan (IHSG) bergerak positif. Selama periode 5-9 Oktober 2015, IHSG menguat 9,07 persen ke level 4.589,3 dibandingkan penutupan pekan sebelumnya pada level 4.207,7. Reaksi positif pelaku pasar juga ditunjukkan melalui rata-rata nilai transaksi harian di Bursa Efek Indonesia (BEI) yang kembali meningkat 35,8 persen menjadi $\operatorname{Rp} 6,65$ triliun dari Rp 4,89 triliun pada sepekan sebelumnya. Ungkap dalam keterangan resmi. Sejalan dengan tren positif tersebut, rata-rata volume transaksi harian juga naik 12,29 persen dan rata-rata frekuensi harian menguat 27,03 persen. Momentum positif penguatan IHSG juga sejalan dengan kembalinya dana investor asing yang mencatatkan beli bersih di pasar saham dalam lima hari terakhir. Selama sepekan terakhir, investor asing kembali mencatatkan net buy Rp 2,26 triliun, meski secara tahunan aliran dana investor asing di pasar saham masih tercatat net sell Rp 10,99 triliun.

Pengumuman paket kebijakan ekonomi $\mathrm{X}$ juga memberikan pengaruh terhadap nilai investasi baik investasi PMA dan PMDN triwulan II dan III 2016 di pulau Jawa tembus Rp250,3 triliun, naik 14,1\% 
dan di luar Jawa Rp 203,1 triliun, naik 12,4 persen. Badan Koordinasi Penanaman Modal (BKPM) menyatakan daerah di luar Jawa yang mengalami peningkatan investasi yang signifikan diantaranya adalah Manado, Nusa Tenggara Barat (NTB) dan Nusa Tenggara Timur (NTT). Investasi yang meningkat menyebabkan kemajuan signifikan dalam pembangunan industri di beberapa kawasan khususnya di luar Jawa yaitu di Sumatera Utara pada pengembangan industri oleokimia. Riau dan kawasan industri Berau di Kalimantan Timur yang dibangun menjadi Palm Oil Grren Economic Zone (POGEZ). Sulawesi Tengah untuk pengembangan industri minyak atsiri dan pengembangan industri feronikel. Kawasan Jawa, di Jawa Tengah menjadi pusat industri ringan (light industry), dan Jawa Timur menjadi pusat industri berat.

Hasil uji untuk hipotesis kedua diterima, artinya terdapat perbedaan reaksi antara sektor usaha yang diuntungkan dengan sektor usaha lainnya. BKPM menyatakan bahwa setelah adanya pengumuman paket kebijakan ekonomi $\mathrm{X}$ investasi asing semakin meningkat. Pada sektor pariwisata triwulan I 2016, investasi asing masuk sebesar US\$ 791 juta dan jumlah yang signifikan terjadi sampai triwulan III mencapai US\$ 1,58 milyar (Rp20,83 triliun). Investasi yang terbesar berada di Jakarta, lalu yang kedua Bali disusul Jawa Barat, Sulawesi Utara dan Nusa Tenggara Barat. Investasi masih mengarah di pembangunan hotel berbintang disusul investasi di consulting management, restoran dan water tourism. Sektor perikanan juga mengalami peningkatan investasi asing, menurut BKPM salah satu investor asing yang akan bekerja sama dengan pemerintah untuk membangun tempat pengolahan perikanan adalah perusahaan asal Rusia, yakni Blackspace. Nilai investasinya mencapai sekitar US\$ 200 juta atau Rp2,6 triliun. Investasi juga mengalir deras pada industri manufaktur menengah dan besar sampai triwulan III 2016 mencapai Rp75, 15 triliun, terdiri atas penanaman modal asing (PMA) dan penanaman modal dalam negeri (PMDN). Investasi itu dikucurkan industri logam, mesin, alat transportasi dan elektronika, serta industri agro.

Pengumuman paket kebijakan ekonomi X memberikan dampak yang positif bagi sektor usaha yang diuntungkan diantaranya meningkatnya penanaman modal asing yang masuk ke berbagai sektor. Sehingga dapat memperkuat modal perusahaan dan membuka lapangan kerja baru, perusahaan dapat memperluas jangkauan dalam memasarkan barang atau jasa di luar Jawa, dan semakin kompetitif dalam bersaing di pasar dalam negeri maupun pasar global. BKPM menyatakan Indonesia berada di peringkat 9 dari 10 negara tujuan utama investasi. Posisi Indonesia dalam negara tujuan investasi naik dari peringkat 14 pada survei 2014 menjadi peringkat 9 pada survei 2016. Tercatat tiga besar negara tujuan investasi adalah Amerika Serikat, Cina dan India, kemudian Inggris, Jerman, Jepang, Brasil, Meksiko, Indonesia dan Malaysia.

\section{SIMPULAN}

Berdasarkan hasil analisis dan pembahasan yang telah dilakukan sebelumnya, maka dapat ditarik simpulan adalah terdapat reaksi pasar atas pengumuman paket kebijakan ekonomi $\mathrm{X}$ tentang daftar negatif investasi (DNI). Berarti bahwa pengumuman paket kebijakan ekonomi $\mathrm{X}$ memiliki kandungan informasi bagi seluruh sektor yaitu sektor pertanian, sektor pertambangan, sektor industri dasar dan kimia, sektor aneka industri, sektor industri barang konsumsi, sektor property, real estate dan konstruksi bangunan, sektor infrastruktur, utilitas dan transportasi, sektor keuangan serta sektor perdagangan, jasa dan investasi. Serta terdapatnya perbedaan reaksi yang terjadi antara sektor usaha yang diuntungkan atas pengumuman paket kebijakan ekonomi X dengan sektor usaha lainnya.

Saran yang dapat disampaikan adalah investor dapat menggunakan informasi paket kebijakan ekonomi X sebagai salah satu indikator dalam pengambilan keputusan. Investor juga mendapatkan informasi untuk mengetahui sektor-sektor yang diuntungkan atas paket kebijakan ekonomi X. Sehingga investor dapat mengumpulkan informasi dan mengkaji informasi tersebut untuk pengambilan keputusan dalam berinvestasi. Pengumuman paket kebijakan ekonomi $\mathrm{X}$ menyebabkan adanya sektor usaha yang diuntungkan dibandingkan dengan sektor usaha lainnya. Maka sebaiknya pemerintah mengkaji atau membentuk suatu paket yang baru agar seluruh sektor usaha juga mendapatkan manfaat dari paket kebijakan ekonomi. Peneliti selanjutnya disarankan untuk menggunakan paket kebijakan ekonomi lainnya seperti paket kebijakan ekonomi XI yang diumumkan pada tanggal 29 Maret 2016 mengatur tentang Kredit Usaha Rakyat Berorientasi Ekspor (KURBE) dan Dana Investasi Real Estate (DIRE). Paket kebijakan ekonomi XII yang diumumkan pada tanggal 28 April 2016 mengatur tentang Ease of Doing Business (EODB). Atau paket kebijakan ekonomi XIII yang diumumkan pada tanggal 24 Agustus 2016 mengatur tentang Perumahan untuk Masyarakat Berpenghasilan Rendah (MBR). Semua paket tersebut bertujuan untuk menarik investor asing masuk ke Indonesia. 


\section{REFERENSI}

Ashley, John W. (1962). Stock Prices and Changes in Earnings and Dividends: Some Empirical. Results. Journal of Political Economy, 70(1), $82-85$.

Ang, Robbert. (1997). Pasar Modal Indonesia (The Intelligent Guide to Indonesian Capital Market). Jakarta: Mediasoft Indonesia.

Aktas, Nihat, Eric de Bodt, \& Richard Roll. (2004). Market Response to Erupean Regulation of Business Combinations. Journal of Financial and Quantitative Analysis, 39(4).

Agrawal, Manish, Rajive Kishore, \& Raghav Rao. (2006). Market Reactions to E business Outsourcing Announcements: An Event Study. Journal Information and Management, 43, 861-873.

Ardi, Azhar, Kiryanto, \& Dista Amalia. (2008). Over Reaksi Pasar Terhadap Harga Saham Perusahaan-Perusahaan di Indonesia (Studi Kasus pada Bursa Efek Indonesia. Tesis. Semarang: Universitas STIE Pelita Nusantara. Amyulianthy, Rafrini, \& Asriyal. (2013). Pengujian Empiris Efficient Market Hypothesis (EMH) Dan Capital Asset Pricing Model (CAPM). Jurnal Liquidity. 2(1), 21-33.

Chandra, Rudy. (2010). Analisis Pemilihan Saham oleh Investor Asing di Bursa Efek Indonesia, 17(2).

Dewi, Ni Putu Shinta. (2015). Evaluasi Efisiensi Pasar Berdasarkan Reaksi atas Stock Split. Tesis. Denpasar : Universitas Udayana.

Fidhayatin, Nurul. (2012). Analisis Nilai Perusahaan, Kinerja Perusahaan dan Kesempatan Bertumbuh Perusahaan terhadap Return Saham pada Perusahaan Manufaktur yang Listing di BEI. The Indonesia Accounting Review, 2(2), 203214.

Fitriani, Sintya Dewi Trisna. (2014). Perbandingan Peristiwa Sebelum dan Sesudah Pemilu Legislatif 2014 Terhadap Harga Saham. Tesis. Palembang: Universitas Islam Negeri Raden Fatah.

Gunarsih, Tri, \& Bambang Hartadi. (2003). Pengaruh Pengumuman Pengangkatan Komisaris Independen Terhadap Return Saham di Bursa Efek Jakarta. Universitas Teknologi Yogyakarta.

Gelb, David. (2007). Payout Composition and Investors Reaction to Dividend and Stock Repurchase Announcements. Social Science
Research Network Electronic Paper Collection.

Hunton, Reck. \& Hayes. (1999). The Market's Reaction to Information Systems Outsourcing Announcement. AMCIS 1999 Proceedings.

Hall, S G, Kenjegaliev A. (2009). Effect of oil price changes on the price of Russian and Chinese oil shares. Working Paper No 09/14. United Kingdom:University of Leicester.

Hartono, Jogiyanto. (2014). Teori Portofolio dan Analisis Investasi. Edisi Kesembilan. Yogyakarta: Universitas Gadjah Mada.

Harlanta, Angga. (2016). Reaksi Pasar Saham Terhadap Pengumuman Paket Kebijakan Ekonomi Pemerintah di BEI. Tesis. Surabaya: Universitas Airlangga.

Ira, Cahyanti. (2005). Pengaruh Peristiwa Politik (Pengumuman Hasil Pemilu, Pengumuman Hasil Pemilihan Presiden, Pengumuman Sususan Kabinet, Reshuffle Kabinet) Terhadap Sektor-Sektor Industri di Bursa Efek Jakarta. www.finansialbisnis.com.

Jarot, Prasetyo. (2004). Efek Model Return Ekspektasi dan Pengelompokan Industri pada Reaksi Pasar Saham di BEJ terhadap Bom Mariott. Tesis. Yogyakarta: Universitas Gadjah Mada.

Jabin, M Ibnu Fajril. (2011). Efisiensi Pasar Sesuai dengan EMH.

Kumar, P Narayan, Narayan Seema. (2009). Modelling the impact of oil prices on Vietnam's stock prices. School of Accounting Economics and Finance. Journal Applied Energy. 87, 356361.

Kurniawati, Sri Lestari, \& Wiwik Lestari. (2011). Pengujian Efisiensi Bentuk Setengah Kuat di Indonesia. Journal of Bussiness and Banking. 1(2), 143-154.

Malhotra, Madhuri, M Thenmozhi, G Arun Kumar. (2007). Stock Market and Liquidity Changes Around Bonus Issue Announcement: Evidence from India. Indian Institute of Capital Markets Paper, 14-32.

May, Ellen. (2012). Pengaruh Investor Asing di Pasar Modal.

Maharani, A.A Istri Agung. (2014). Respon Pasar atas Informasi Laba (Replikasi Ball dan Brown 1968). E-Jurnal Akuntansi Universitas Udayana, 83-93.

Oberndorfer, U, Ziegler A. (2006). Environmentally Oriented Energy Policy and Stock Returns: An 
Empirical Analysis. Center For European Economic Research Discussion Paper No. 06-079.

Suryawijaya, Marwan Asri, \& Faizal Arief Setiawan.

(1998). Reaksi Pasar Modal Indonesia Terhadap

Peristiwa Politik Dalam Negeri (Event Study pada Peristiwa 27 Juli 1996). KELOLA, 7(18), 137-153.

Sugiyono. (2014). Metode Penelitian Kuantitatif, Kualitatif, dan Kombinasi (Mixed Methods). Bandung : Alfabeta. 